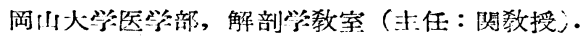

Anat. Inst. d. Med. Fak. Okayama (Vorstand : Prof. M. SEKI).

\title{
人の諾軟骨基啠の超構密度の此較觀察.
}

\section{Vergleichende Beobachtung der Ultrastrukturdichte der verschiedenen Knorpelgrundsubstanz des Menschen.}

\section{藤 井大 輔 Daisuke FUJII.}

(昭和 25 年 10 月 3 日原稿受附)

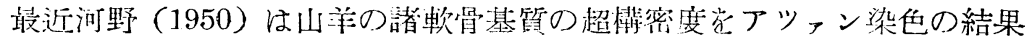
から観祭し，非関節軟骨のものが関節軟骨のものに比して一般に大である てとを認め，人の $2-3$ の軟骨につんてもてれを確めた。 てれは注意に值 する事実であつて，私は更に多くの人の硝子軟骨に就き比較钼祭を行つた のである。

\section{I. 材料 と 方 法.}

人屍 (24藏, 早) から 200 関節軟骨之 5 の非関節軟骨它切り取り，10\%ホ

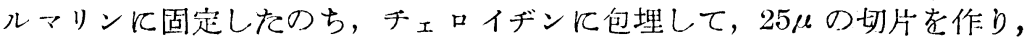
関（昭26）の安息香酸メチル張附法によつて載せガラスに貼り。チェロイ ヂンを溶し去つた，色調之分散度の晎なる酸性染料之しては，大倉（昭25）

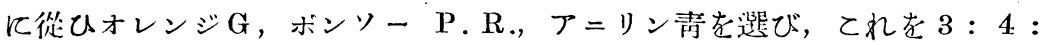
3 の製に混じて醋酸よ醋酸ナトリウムで作つた $\mathrm{pH} 4.0$ の緩衝液に溶し，

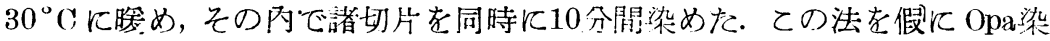
色之呼ぶ. 别に諸切片を $4 \%$ \%鐵明樊にて 10 分䦎前処理し，1\%鐵へマトキ シリンで20分間染めてのち，2\%鐵明攀に5 分間清けて切片の脫色の度を 比較した．正しん相当像を得るためには互に比較せらるべき軟骨は同時に 固定し，同時に薄切し，同時に染色し，且つ同時に後処理せられねばなら ぬ.

軟骨の切取部位を詳しく云ふっ之，関節軟骨は上腕骨頭（頂一之外側部）， 上腕骨小頭 (頂- 之外側部)， 上骨小頭 (頂-之外側部)，中手骨小頭(第 1 ，第 3 ，第 5 中手骨)，大腿骨頭 (頂-之外側部)，大腿骨脛側顆 (頂- 之 外側部)，脛骨踝 (頂部)，腓骨踝 (頂-之外側部), 中足骨小頭 (節 1 ，第 3 ，箁 5 中足骨），鎻骨の胸骨端 (頂部) からで，非関節軟骨は學中隔軟 骨，鼻䔬軟骨，気營軟骨，甲狀軟骨，第 3 助軟骨中央部であつた。 


\section{II. 實 驗の 結 果.}

確実のため標本製作を $3-4$ 回反覆した。実験の結果を見易くするため

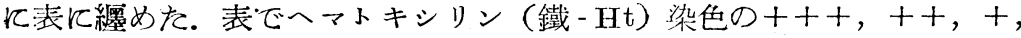
土は染色の强さを示す。

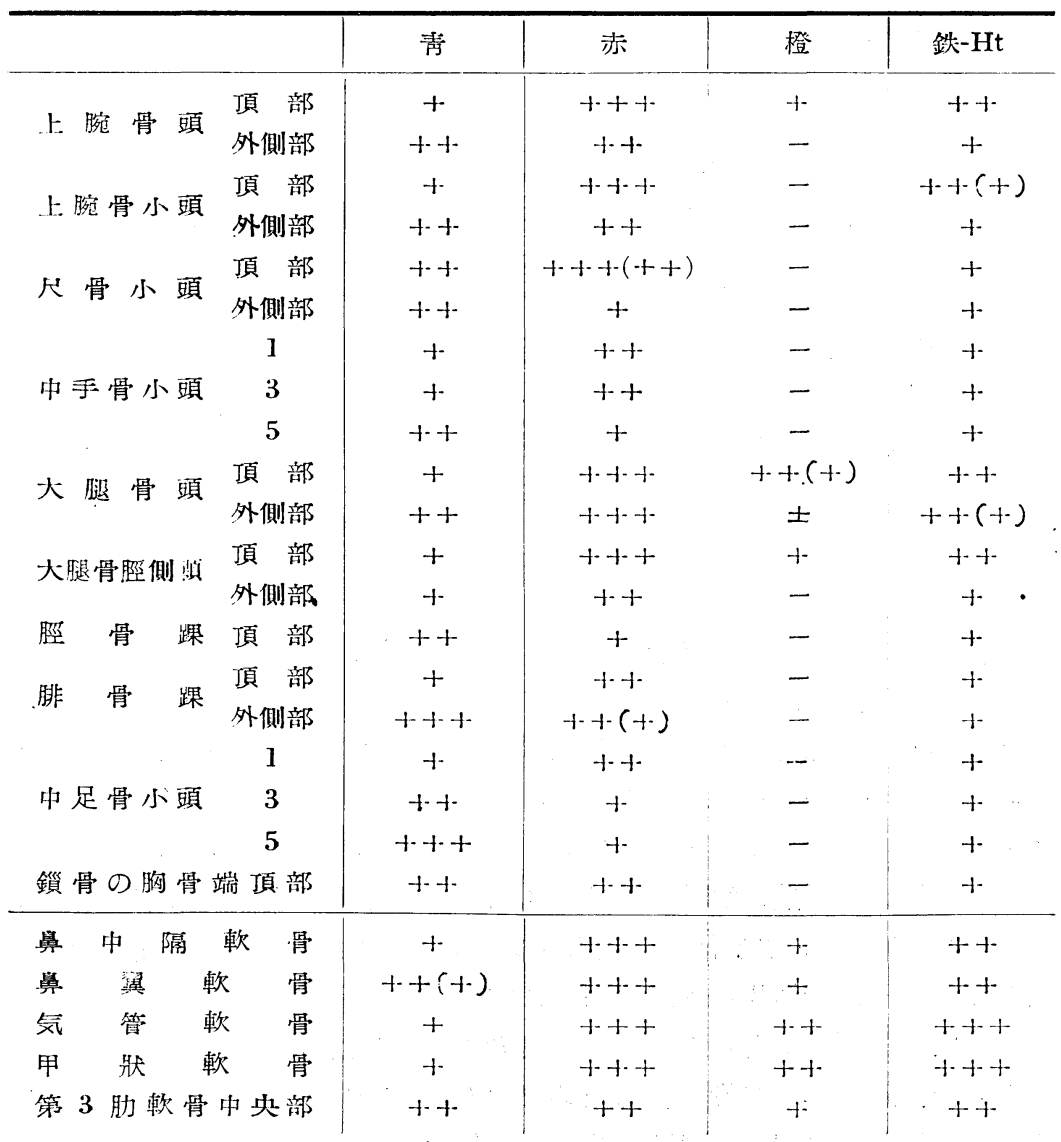

染色の結果を関節軟骨之非関節軟骨に分けて說明すれば，

\section{1. 關節軟 骨 (図 $1-6$ ).}

各軟骨とも概して表層の基質は毒染し，楧密度の低んことを示す。また 同一軟骨では外側部の方が頂部よりも青染の度が强ん．軟骨により著しん

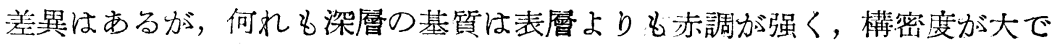
あることを示してんる。

中手骨小頭之中足骨小頭を除けば，概して下肢骨の軟骨はそれて相当す 


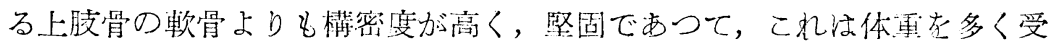
けるためであらう。

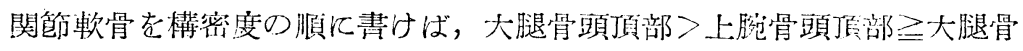

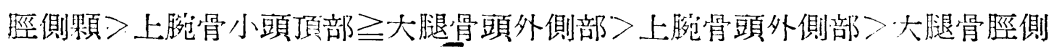

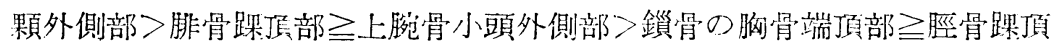
部>尺骨小頭頂部》中手骨小頭 (第 1 中手骨) >中手骨小頭 (第 3 中手骨) $>$ 中足骨小頭 (第 1 中足骨) $>$ 腓骨踝外側部 $\geqq$ 尺骨小頭外側部 $>$ 中手骨小 頭 (第 5 中手骨) $\geqq$ 中足骨小頭 (第 3 中足骨) >中足骨小頭 (第 5 中足骨) である。

\section{2. 非關節軟 骨 (図7-8).}

非関節軟骨基質は概して関節軟骨よりも淡く染り，染るべき物質には乏

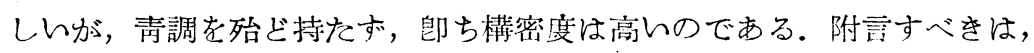

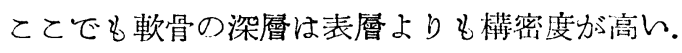

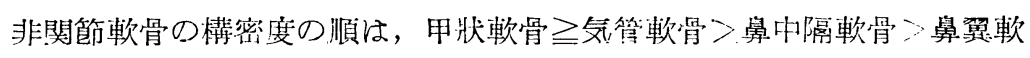
骨 第 3 肋軟骨中央部である。

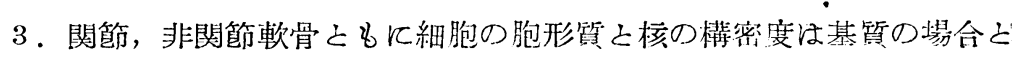

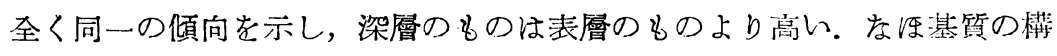
密度が高ん軟骨では細胞の椿密度がそれの低ん軟骨のものよりやや大であ るととが見られた。

\section{III. 考察.}

上述の結果を考察するに，関節－と非関節軟骨ともに基質は軟骨の表層 では大分子染料にて强く染り柾構で，深㾝では小分子染料により强く染り 密構である. 蓋し Benninghoff (1925) や河野(1950)が注意した如く, 軟 骨が彎曲されれば，軟骨表膚が最も强く表面に平行の方向に旁引されるか

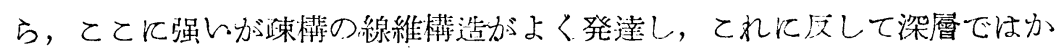
かる外力の影隌多心少く，基質は未分化な物筫に富み，線維の発洼はわるい もの亡解せられる。

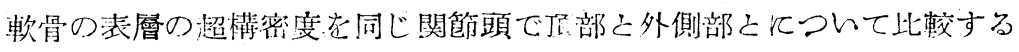
そ，顶部は外側部に比し小分子染料にて强く染まり密構である。毁ち表面

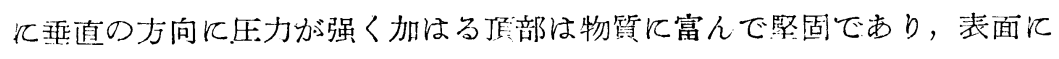

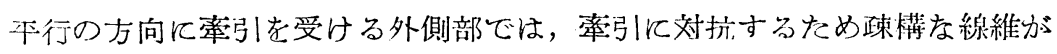


よく発達している。

次に関節 - 之非関節硝子軟骨につを基質の染色性艺比較するに，河野 (1950) が悬中隔軟骨之 $2-3$ の関節軟骨之で見た如く，関節軟骨は非関

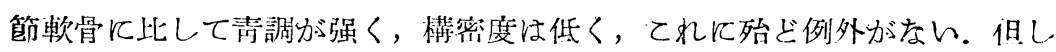
赤染の强さは関節軟骨が勝る。郎ち関節軟骨の基筫は染められるべさ物管

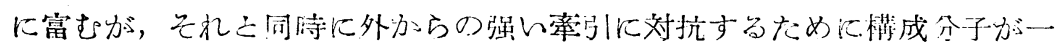
定の方向に配列して分子䇣を作り，分子素は更に集つて原線維を生じ，そ

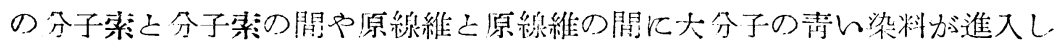

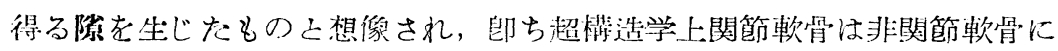
比し分化の度が菖い之云ふべきである。

最後に鐵へマトキシリン染色之Opa 染色の結果を比較するに，小分子染 料で强く染められる密構の軟骨茞ど，鐵へマトキシリンが一旦染めると， てれが去り難いととが確められ，乙の方法からも上述の結果が正しいとと が知られた。

\section{IV. 結語.}

人の 25 硝子軟骨を採り，オパ（オレンジーボンソーーアニリン表）染色 により超檴密度を比較観祭した。

1. 関節軟骨壮非関節軟骨に比して一般に超满密度が低ん，䢴ち線維構 造がよく発涬し，軟骨としては超構造学上分化の度が高んと元ふべきであ る.

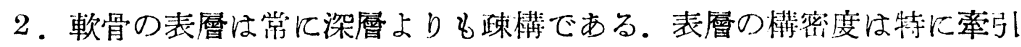
力が表面に平行の方向に强く加るとてろに低く, 即ちててに線維樺造の発 澾がよん。

3. 概して下肢の軟骨の超檴密度は上肢のものより高ん.

4.鐵へマトキシリン染色後の脫色所見は上記の事夷を確めた。

\section{Autoreferat.}

Die Ultrastrukturdichte der Grundsubstanz von. 25 hyalinen Knorpeln des Menschen wurde nach der Oparärbung (Orange-Ponçau-Anilinblau) untersucht. Es wurde bestätigt, daß die Ultrastrukturdichte der Gelenkknorpel in der Regel niedriger ist als diejenige der Nichtgelenkknorpel, indem die Faserstruktur sich in ihnen gut entwickelt, daß fərner die oberflächliche Schicht des Knorpels im Vergleich zu der tieferen. Schicht immer lockerer strukturiert ist. Es ist anzunehmen, daß die Gelenkknorpel submikroskopisch höher difïrenziert sind als diə Nichtgelenkknorpel. 


\section{文献}

Benninghoff, A. : Über den funktionellen Bau des Knorpels. Verh. anat. Ges. 31 (1922). -- Kono, S.: Vergleichende Beobachtung der submikroskopischen Strukturdichte der Verschiedenen Knorpelgrundsubstanz der Ziege. Arch. hist. ja .1 1 (1950). 一 大良卓治：構密变と染色性の関係のモデル実験・日組錄・1

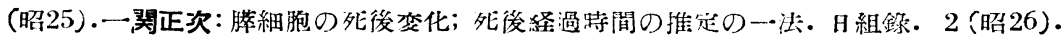

\section{附圖の說明.}

すべてホルマリン周定, チェロイヂン切版ら期チェロイヂンしてオパ(オレンジー ポンソーーアニリン等) 染色.

汹1 上腕骨小頭頂部の軟骨.

汹2, 火骨小頭頂部の軟骨.

兴 3．中手骨小頭 (第1 中手骨) の軟骨.

比 4 . 火腿骨頭頂部の軟骨.

汹 5 . 大腿骨頭外側部の軟骨.

必 6 . 跳骨踝頂部の軟骨.

汹 7 . 其中隔の軟骨.

湿 8 . 甲狀の軟骨.

Erklärung der Tafelabbildungen.

Formalinfixierung. Die Zelloidinschnitte der Knorpel wurden nach der Auslösung des Zelloidins nash der Opafärbung (Orange-Ponceau-Anilinblau) gefärbt.

Abb. 1. Knorpel aus dem Scheitel des Capitulum humeri.

Abb. 2. Derselbe aus dem Scheitel des Capitulum ulnae.

Abb. 3. Darselbe des Capitulum metacarpi.

Abb. 4. Dersel be aus dem Ssheitel des Cayut femoris.

Abb. 5. Derselbe aus dem lateraler Tl. des Caput femoris.

A bb. 6. Derselte aus dem Scheitel des Malleolus fitulae.

Abb. 7. Nasens cheidewand knorpel.

Abb. 8. Schildknorpel. 
藤井大輔

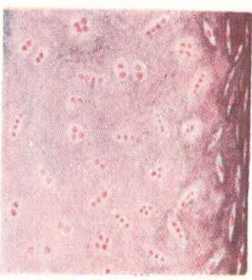

1

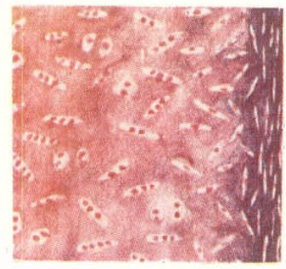

4

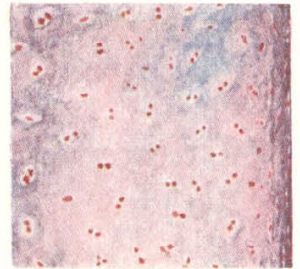

2

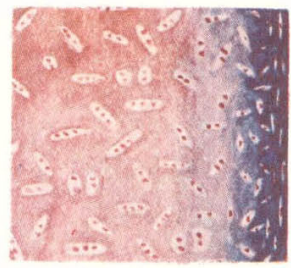

5

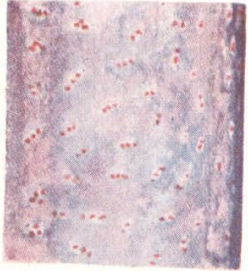

3

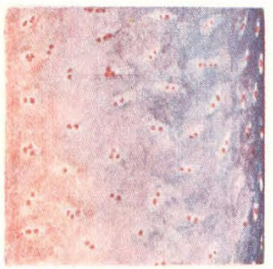

6

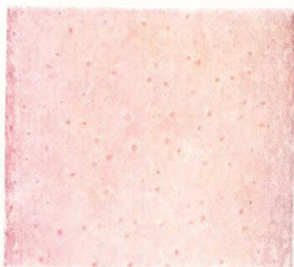

7

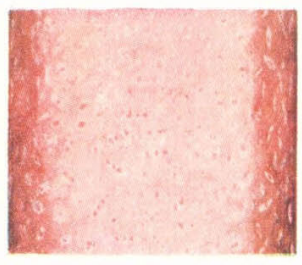

8 